\title{
PENERAPAN REGRESI COMPLEMENTARY LOG-LOG DALAM ANALISIS KEMISKINAN ANAK DI DAERAH PERKOTAAN DI PROVINSI BENGKULU TAHUN 2018
}

\author{
(Application of Complementary Log-Log Regression in the Analysis of Child Poverty in \\ Urban Areas in Bengkulu Province in 2018)
}

\author{
Maria Megachita da Silva1, ${ }^{1}$ Agung Priyo Utomo \\ Politeknik Statistika STIS ${ }^{1}$ \\ Politeknik Statistika STIS 2 \\ Jl. Otto Iskandardinata No. 64C, Kel. Bidara Cina, Kec. Jatinegara, Kota Jakarta Timur, DKI Jakarta 13330 \\ E-mail: 111709810@stis.ac.id
}

\begin{abstract}
ABSTRAK
Kemiskinan anak merupakan suatu masalah yang perlu mendapat perhatian khusus, mengingat anak merupakan generasi masa depan bangsa. Kemiskinan anak erat kaitannya dengan kemiskinan rumah tangga. Melalui pendekatan moneter, seorang anak usia 0-17 tahun dikatakan mengalami kemiskinan jika tinggal dalam rumah tangga dengan rata-rata pengeluaran per kapita per bulan berada di bawah garis kemiskinan. Lokus penelitian ini adalah Provinsi Bengkulu yang berangkat dari temuan bahwa tingkat kemiskinan anak di Provinsi Bengkulu tertinggi di antara provinsi di Pulau Sumatera pada tahun 2016. Penelitian ini lebih difokuskan untuk menganalisis kemiskinan anak di daerah perkotaan. Penelitian ini menggunakan data hasil Praktik Kerja Lapangan Mahasiswa Politeknik Statistika STIS Tahun Akademik 2017/2018 yang diselenggarakan di Provinsi Bengkulu. Metode analisis yang digunakan adalah regresi nonlinier dengan fungsi hubung complementary log-log dengan metode backward elimination. Hasil analisis menunjukkan bahwa anak yang tinggal dengan kepala rumah tangga berusia lebih muda, dengan pendidikan kepala rumah tangga yang ditamatkan di bawah SMA, anak yang tinggal dalam rumah tangga yang berukuran lebih dari empat orang anggota rumah tangga, dan anak yang tinggal di rumah tangga yang tidak memiliki perilaku menabung lebih berisiko untuk mengalami kemiskinan anak.
\end{abstract}

Kata kunci: Kemiskinan anak, perkotaan, complementary log-log, Praktik Kerja Lapangan

\section{ABSTRACT}

Child poverty is a problem that needs special attention, considering that children are the future generation of the nation. Child poverty is closely related to household poverty. Through a monetary approach, a child aged 0-17 years is said to experience poverty if he lives in a household with average per capita monthly expenditure below the poverty line. The locus of this research is Bengkulu Province, based on finding that the level of child poverty in Bengkulu Province is highest among the provinces on Sumatra Island in 2016. This research is more focused on analyze child poverty in urban areas. This study uses data from the Field Work Practice of Politeknik Statistika STIS Academic Year 2017/2018 held in Bengkulu Province. The analytical method used is nonlinier regression with complementary log-log link function with backward elimination. The results of the analysis show that children who live with household heads are younger, with the education of household heads who are graduated below high school, children who live in households that are more than four household members, and children who live in households that are not having saving behavior is riskier to experience child poverty.

Keywords: Child poverty, urban, complementary log-log, Field Work Practice

\section{PENDAHULUAN}

Fenomena kemiskinan masih menjadi salah satu tantangan global dan menjadi masalah yang masih melekat dalam kehidupan masyarakat terutama bagi negara berkembang, seperti Indonesia. World Bank (2000) mendefinisikan kemiskinan sebagai suatu situasi kehilangan kesejahteraan atau 
merupakan suatu kondisi ketidakberdayaan. Bermacam upaya telah dilakukan untuk menanggapi tantangan global ini, seperti yang tertuang dalam program Sustainable Development Goals (SDGs) pada tujuan pertama yang berbunyi "No Poverty" atau dengan kata lain mengakhiri kemiskinan dalam segala bentuk dan di mana pun (United Nations, 2019).

Persentase penduduk miskin di Indonesia menurut Badan Pusat Statistik (BPS) pada Maret 2018 menyentuh angka 9,82 persen atau sekitar 25,95 juta penduduk di Indonesia termasuk kategori penduduk miskin. Berdasarkan angka tersebut, akhirnya tingkat kemiskinan di Indonesia dapat menembus satu digit pada Maret 2018. Walaupun demikian, masih terbilang cukup jauh dari sasaran Rancangan Pembangunan Jangka Menengah (RPJMN) 2015-2019 yang menargetkan tingkat kemiskinan berada di kisaran 7,00-8,00 persen pada akhir periode RPJMN 2015-2019. BPS mendefinisikan kemiskinan sebagai ketidakmampuan dari sisi ekonomi dalam pemenuhan kebutuhan dasar baik berupa makanan maupun nonmakananan dengan rata-rata pengeluaran perkapita di bawah garis kemiskinan.

Dampak dari fenomena kemiskinan tidak hanya dirasakan oleh orang dewasa, namun juga anak-anak. Menurut Undang-Undang Nomor 35 Tahun 2014 tentang Perubahan atas UndangUndang Nomor 23 Tahun 2002 tentang Perlindungan Anak, anak didefinisikan sebagai seseorang yang belum berusia 18 tahun, termasuk anak yang masih dalam kandungan. Menurut hasil proyeksi penduduk oleh BPS, pada tahun 2018 sebesar 30,1 persen atau sebanyak 79,55 juta jiwa penduduk Indonesia adalah anak-anak berusia 0-17 tahun. Dengan kata lain, sepertiga dari penduduk Indonesia pada tahun 2018 adalah anak-anak (Badan Perencanaan Pembangunan Nasional et al., 2013).

Dalam penelitian ini, kemiskinan anak diukur melalui pendekatan moneter. Badan Pusat Statistik \& UNICEF (2017) mendefinisikan kemiskinan anak secara moneter adalah anak usia 0-17 tahun yang tinggal di rumah tangga miskin, yaitu rumah tangga yang rata-rata pengeluaran perkapitanya per bulan berada di bawah garis kemiskinan. Akan sulit bagi seorang anak untuk terlepas dari efek kemiskinan jika ia hidup dalam rumah tangga yang miskin. Kondisi rumah tangga akan sangat berpengaruh pada status kemiskinan anak. Kumala et al. (2013) menyatakan bahwa anak yang tinggal dan hidup dalam rumah tangga yang miskin, maka secara otomatis akan mengalami kemiskinan. Ketidakmampuan anak dalam memenuhi kebutuhan ekonomi secara mandiri mengakibatkan mereka harus bergantung pada orang-orang di sekelilingnya.

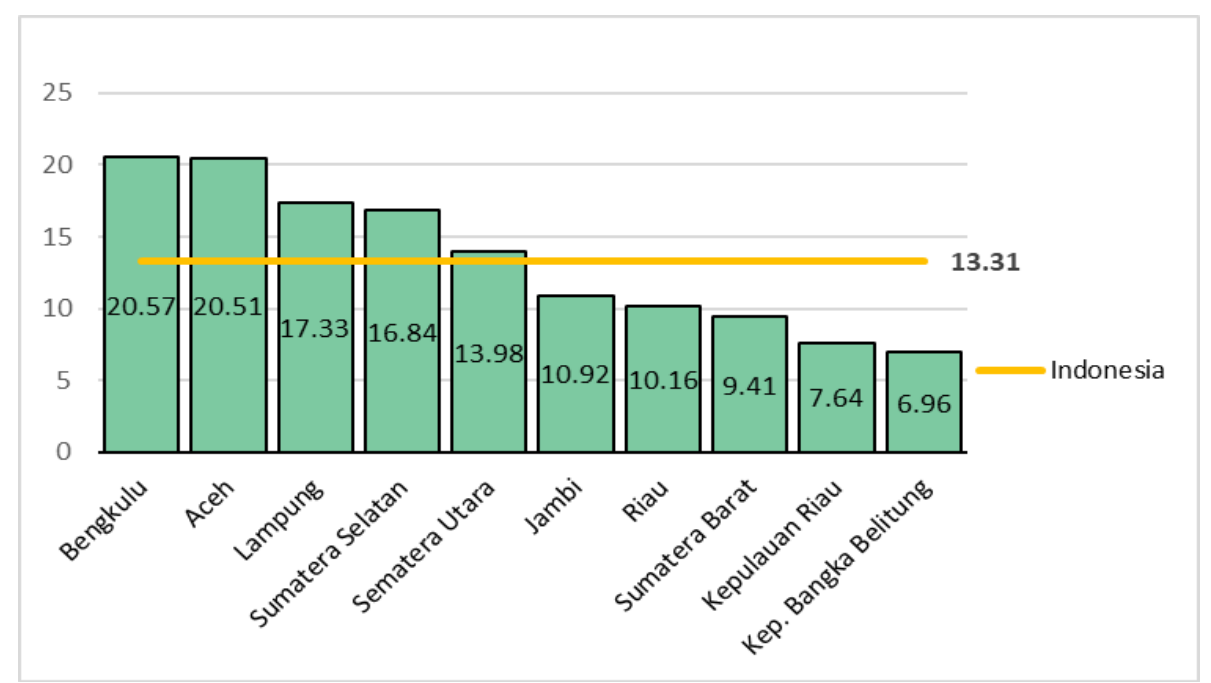

Sumber : Badan Pusat Statistik

Gambar 45. Persentase Penduduk yang Hidup di Bawah Garis Kemiskinan Nasional menurut Kelompok Umur Tahun 2015-2018.

Berdasarkan Gambar 1, terlihat bahwa persentase penduduk yang hidup di bawah garis kemiskinan nasional sejak Maret 2015 hingga Maret 2018, baik pada kategori penduduk usia di bawah 18 tahun (anak) maupun pada kategori penduduk usia 18 tahun ke atas memiliki pola yang sama, yaitu menunjukkan pola yang menurun tiap periode waktu. Hal ini menunjukkan bahwa kemiskinan pada anak sejalan dengan kemiskinan rumah tangga. Namun, persentase penduduk 
usia di bawah 18 tahun yang hidup di bawah garis kemiskinan nasional selalu lebih tinggi daripada pada kategori penduduk usia 18 tahun ke atas sejak Maret 2015 hingga Maret 2018. Hal ini mengindikasikan anak-anak lebih berisiko untuk mengalami kemiskinan daripada penduduk pada kelompok umur lainnya.

Menurut BPS dan UNICEF dalam Analisis Kemiskinan Anak dan Deprivasi Hak-Hak Dasar Anak di Indonesia menunjukkan tingkat kemiskinan anak di Indonesia pada tahun 2016 sebesar 13,31 persen. Menurut kelompok pulau, Pulau Sumatera berada di posisi ketiga dengan tingkat kemiskinan anak sebesar 14,22 persen. Sementara itu, Pulau Sumatera memiliki angka poverty share (proporsi anak miskin) tertinggi kedua setelah Pulau Jawa, yaitu sebesar 25,34 persen. Angka poverty share tersebut menunjukkan seperempat dari seluruh anak miskin di Indonesia berada di Pulau Sumatera. Berikut disajikan data persentase anak miskin menurut provinsi di Pulau Sumatera tahun 2016.

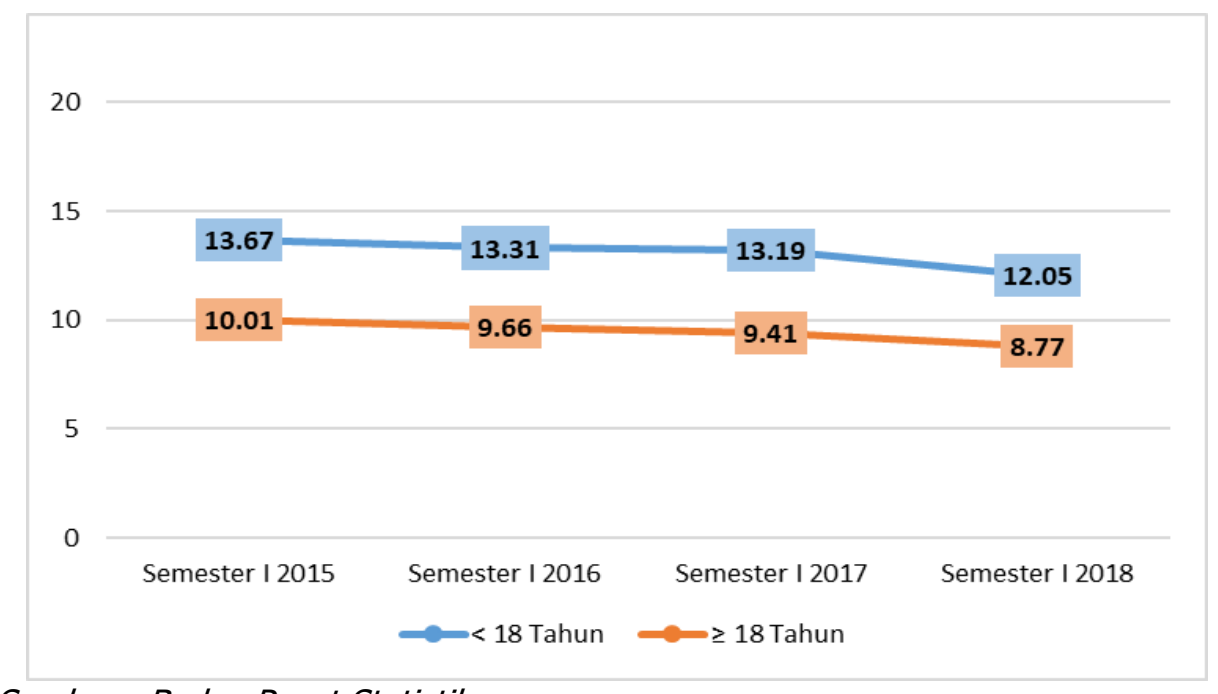

Sumber : Badan Pusat Statistik

Gambar 2. Tingkat Kemiskinan Anak menurut Provinsi di Pulau Sumatera Tahun 2016.

Berdasarkan Gambar 2, Provinsi Bengkulu memiliki tingkat kemiskinan anak tertinggi di tahun 2016, yaitu mencapai 20,57 persen. Sedangkan provinsi dengan persentase anak miskin terendah di Pulau Sumatera, yaitu Provinsi Kepulauan Bangka Belitung dengan persentase anak miskin hanya sebesar 6,96 persen. Dari gambar tersebut, dapat dilihat juga bahwa sebagian provinsi di Pulau Sumatera memiliki persentase anak miskin lebih besar daripada persentase anak miskin nasional. Provinsi yang dimaksud antara lain : Provinsi Bengkulu, Provinsi Aceh, Provinsi Lampung, Provinsi Sumatera Selatan, dan Provinsi Sumatera Utara.

Salah satu target pada tujuan pengentasan kemiskinan dalam program SDGs, yaitu pada tahun 2030 ditargetkan setidaknya mengurangi separuh proporsi laki-laki, perempuan, dan anakanak di segala usia yang hidup dalam kemiskinan. Mengacu dari target tersebut, maka kemiskinan anak termasuk mendapat tempat khusus dalam program SDGs. Dalam Pasal 28B Ayat (2) UndangUndang Dasar 1945 menyatakan bahwa setiap anak berhak atas kelangsungan hidup, tumbuh, dan berkembang, serta berhak atas perlindungan dari kekerasan dan diskriminasi.

Menurut BPS dan UNICEF dalam Analisis Kemiskinan Anak dan Deprivasi Hak-Hak Dasar Anak di Indonesia, tingkat kemiskinan anak yang tinggal di daerah perkotaan pada tahun 2016 sebesar 9,77 persen. Sejauh ini, masih sedikit peneliti yang mengkaji tentang kemiskinan anak khususnya yang tinggal di daerah perkotaan. Bartlett (2012) menyatakan bahwa pola pikir masyarakat tentang anak-anak yang tinggal di perkotaan umumnya memiliki kehidupan yang lebih baik daripada anak-anak yang tinggal di daerah perdesaan. Hal ini dapat dilihat melalui kemudahan dalam mengakses sarana dan prasarana baik dalam bidang kesehatan maupun pendidikan, juga peluang untuk berhasil dalam hidup yang lebih tinggi untuk anak-anak perkotaan. Namun, menurut Bima et al. (2017) keberadaan anak-anak yang mengalami kemiskinan dan tinggal di daerah perkotaan di Indonesia sering kali tidak terjamah oleh kebijakan pemerintah, khususnya di daerah kumuh perkotaan. Akibatnya anak-anak tersebut dikecualikan dan tidak dapat menikmati 
pelayanan dasar yang memadai. Ditambah lagi dengan biaya hidup yang tinggi di daerah perkotaan dapat membebankan suatu rumah tangga dalam memenuhi kebutuhan hidupnya. Hal ini berujung pada anak yang dipaksa bekerja demi membantu ekonomi rumah tangga dan membuat mereka harus berada di lingkungan yang berisiko.

Pada tahun 2018 dilakukan penelitian dalam bentuk Praktik Kerja Lapangan (PKL) oleh mahasiswa Politeknik Statisika STIS yang dilaksanakan di Provinsi Bengkulu dengan tema "Kajian Kemiskinan dan Perspektif Pengeluaran dan Perilaku Menabung serta Determinannya di Provinsi Bengkulu Tahun 2018". Dengan menggunakan metode Small Area Estimation dan sampel sebanyak 6.930 rumah tangga, diperoleh persentase penduduk miskin di Provinsi Bengkulu pada tahun 2018 sebesar 15,72 persen. Hasil ini tidak jauh berbeda dengan angka persentase penduduk miskin di Provinsi Bengkulu pada Maret 2018 oleh BPS, yaitu sebesar 15,43 persen. Sejauh ini data hasil PKL yang telah dikumpulkan belum dikaji lebih lanjut dan dimanfaatkan dalam penelitianpenelitian lanjutan dalam rangka memperoleh temuan baru.

Rumah tangga, khususnya orang tua, menjadi salah satu faktor penting dalam memengaruhi kesejahteraan anak-anak. Bima et al. (2017) menyatakan kemiskinan rumah tangga dianggap sebagai akar dari berbagai masalah yang dihadapi oleh anak-anak, misalnya anak-anak yang tidak dapat menikmati kondisi kehidupan yang lebih baik dan kesulitan dalam mengakses layanan publik, seperti layanan kesehatan dan pendidikan. Oleh karena itu, penting untuk meneliti kemiskinan anak yang tinggal di daerah perkotaan berdasarkan karakteristik rumah tangga dengan memanfaatkan data hasil PKL Mahasiswa Politeknik Statistika STIS TA 2017/2018.

Metode analisis yang cocok digunakan ketika variabel respons berupa data kategorik dan dikotomi adalah regresi nonlinier atau regresi logistik biner. Dalam regresi logistik biner terdapat beberapa fungsi hubung, seperti logit, probit, dan complementary log-log. Heck (2013) menyatakan bahwa penggunaan metode regresi nonlinier dengan fungsi hubung complementary log-log akan lebih cocok dan memberikan keuntungan ketika digunakan untuk menangani kasus dengan data pada variabel responsnya memiliki probabilitas sangat besar atau sangat kecil pada salah satu kategorinya. Anak yang tinggal di daerah perkotaan dan mengalami kemiskinan dapat dikatakan merupakan suatu kejadian yang rare, mengingat tingkat kemiskinan anak di daerah perkotaan tahun 2016 sebesar 9,77 persen (Badan Pusat Statistik \& UNICEF, 2017). Suatu kejadian dikatakan rare jika probabilitas kejadian tersebut di bawah 20 persen (Calabrese, 2014).

Berdasarkan uraian di atas, tujuan dari penelitian ini, yaitu untuk mengetahui gambaran umum mengenai kemiskinan anak di daerah perkotaan dan menganalisis variabel-variabel yang memengaruhi kemiskinan anak di daerah perkotaan di Provinsi Bengkulu tahun 2018 dengan menerapkan metode regresi nonlinier dengan fungsi hubung complementary log-log.

\section{METODE}

\section{Landasan Teori}

Definisi anak dalam Konvensi Hak Anak oleh Perserikatan Bangsa-Bangsa adalah semua orang yang berusia di bawah 18 tahun, kecuali ditentukan lain oleh hukum suatu negara (United Nations, 2018). Indonesia kemudian mengadopsi konvensi tersebut dalam Undang-Undang Nomor 23 Tahun 2002 tentang Perlindungan Anak yang kemudian direvisi pada tahun 2014 dan menghasilkan Undang-Undang Nomor 35 Tahun 2014. Dalam Pasal 1 Ayat (1) Undang-Undang Nomor 35 Tahun 2004, anak didefinisikan sebagai seseorang yang belum berusia 18 tahun, termasuk anak yang masih dalam kandungan.

Save the Children (dalam Pusponegoro (2013)) melalui pendekatan moneter menyatakan bahwa anak dikatakan miskin apabila tinggal dalam keluarga yang miskin. Kumala et al. (2013) dalam penelitiannya juga menjelaskan bahwa anak yang tinggal dan hidup dalam rumah tangga yang miskin, maka ia pun secara otomatis mengalami kemiskinan. Sejalan dengan definisi tersebut, Badan Pusat Statistik \& UNICEF (2017) mendefinisikan kemiskinan anak secara moneter merupakan anak yang berusia 0-17 tahun yang tinggal di rumah tangga miskin, yaitu rumah tangga yang rata-rata pengeluaran per kapita per bulan berada di bawah garis kemiskinan. BPS juga menyatakan bahwa kondisi rumah tangga akan sangat berpengaruh pada anak, apakah 
menjadi miskin atau tidak. Akan sulit bagi seorang anak untuk terlepas dari efek kemiskinan jika ia hidup dalam rumah tangga yang miskin.

Seperti yang diatur dalam Peraturan Kepala Badan Pusat Statistik Nomor 37 Tahun 2010 tentang Klasifikasi Perkotaan dan Perdesaan di Indonesia, daerah perkotaan didefinisikan sebagai suatu wilayah administratif setingkat desa/kelurahan yang memenuhi persyaratan tertentu dalam hal penduduk, persentase rumah tangga pertanian, dan sejumlah fasilitas perkotaan, sarana pendidikan formal, sarana kesehatan umum, dan sebagainya. Terdapat tiga indikator sebagai ukurannya, yaitu kepadatan penduduk per kilometer persegi, persentase rumah tangga pertanian, dan keberadaan atau akses untuk mencapai fasilitas perkotaan.

\section{Cakupan Penelitian}

Penelitan ini meneliti tentang variabel-variabel yang memengaruhi status kemiskinan anak yang tinggal di wilayah perkotaan di Provinsi Bengkulu tahun 2018 dengan menggunakan data sekunder dari raw data hasil Praktik Kerja Lapangan Mahasiswa Politeknik Statistika STIS Tahun Akademik 2017/2018. Unit analisis dalam penelitian ini adalah anggota rumah tangga yang berusia 0-17 tahun. Penghitungan status kemiskinan anak dalam penelitian ini menggunakan pendekatan moneter. Variabel respons yang digunakan berupa status kemiskinan anak yang berupa data kategorik, yaitu anak yang mengalami kemiskinan dan anak yang tidak mengalami kemiskinan. Sedang variabel penjelas yang digunakan, yaitu umur Kepala Rumah Tangga (KRT), tingkat pendidikan KRT, jenis kelamin KRT, status pekerjaan KRT, ukuran rumah tangga, dan perilaku menabung berdasarkan hasil tinjauan dari penelitian-penelitian terkait.

\section{Metode Analisis}

Metode analisis yang digunakan dalam penelitian ini, yaitu analisis desktiptif dan inferesia. Program aplikasi statistik yang digunakan untuk mengolah data, yaitu program Microsoft Excel 2016 dan $R$ Studio.

Analisis Deskriptif

Analisis deskriptif digunakan untuk menggambarkan secara umum pola sebaran dari anak usia 0-17 tahun yang tinggal di daerah perkotaan di Provinsi Bengkulu tahun 2018 dan variabel status kemiskinan anak juga variabel-variabel penjelas yang disajikan dalam tabel dan grafik.

Analisis Inferensia

Selain analisis deskriptif, peneliti juga menggunakan analisis inferensia untuk mengetahui variabel-variabel yang signifikan memengaruhi status kemiskinan anak yang tinggal di daerah perkotaan di Provinsi Bengkulu tahun 2018. Penelitian ini menggunakan metode regresi nonlinier dengan fungsi hubung complementary log-log. Model regresi complementary log-log yang dapat dibentuk dengan meregresikan variabel respons dengan variabel penjelas sebagai berikut :

$$
\begin{aligned}
g(x)= & \beta_{0}+\beta_{1} \text { UmurKRT }+\beta_{2} \text { TingkatPendidikanKRT }+\beta_{3} \text { JenisKelaminKRT }+\beta_{41} \text { StatusPekerjaanKRT } \\
& +\beta_{42} \text { StatusPekerjaanKRT }+\beta_{5} \text { UkuranRuta }+\beta_{6} \text { PerilakuMenabung } \ldots \ldots \ldots \ldots \ldots \ldots \ldots \ldots \ldots . . . \ldots \ldots \ldots \ldots \ldots \ldots \ldots
\end{aligned}
$$

Pengujian parameter secara simultan dengan statistik uji Likelihood Ratio (G) digunakan untuk mengetahui apakah minimal ada satu variabel bebas yang signifikan di dalam model. Kemudian uji parsial dengan statistik uji Wald digunakan untuk menghitung koefisien regresi untuk setiap variabel penjelas dan bagaimana pengaruhnya apakah nyata atau tidak terhadap variabel respons. Pendugaan parameter model menggunakan metode backward elimination, dengan mereduksi satu-satu variabel yang tidak signifikan pada setiap tahapan. Uji kesesuaian model dengan statistik uji Hosmer dan Lemeshow digunakan untuk menguji apakah model yang terbentuk sudah cukup sesuai untuk menjelaskan variabel tak bebas. Interpretasi pada persamaan regresi complementary log-log yang terbentuk dilakukan melalui nilai $\exp \left(b_{j}\right)$ yang menyatakan besaran risiko untuk masing-masing variabel penjelas yang memengaruhi variabel status kemiskinan anak yang tinggal di daerah perkotaan di Provinsi Bengkulu pada tahun 2018. 


\section{HASIL DAN PEMBAHASAN}

\section{Gambaran Umum dan Karakteristik Kemiskinan Anak di Daerah Perkotaan di Provinsi Bengkulu Tahun 2018}

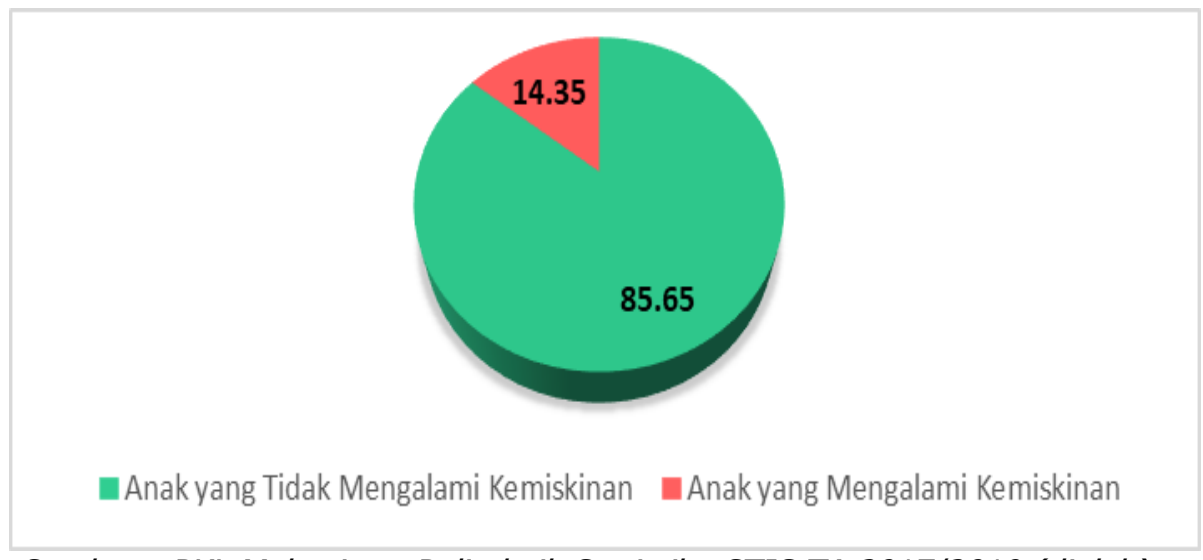

Sumber : PKL Mahasiswa Politeknik Statistika STIS TA 2017/2019 (diolah)

Gambar 3. Persentase Status Kemiskinan Anak di Daerah Perkotaan di Provinsi Bengkulu Tahun 2018.

Gambar 3 menyajikan data persentase anak yang mengalami kemiskinan dan yang tidak mengalami kemiskinan yang tinggal di daerah perkotaan di Provinsi Bengkulu tahun 2018. Dapat dilihat bahwa persentase anak yang tinggal di daerah perkotaan dan mengalami kemiskinan lebih kecil dibandingkan dengan anak yang tinggal di perkotaan dan tidak mengalami kemiskinan. Persentase anak yang tinggal di perkotaan dan mengalami kemiskinan sebesar 14,35 persen. Sedangkan persentase anak yang tinggal di perkotaan dan tidak mengalami kemiskinan sebesar 85,65 persen.

Tabel 30. Karakteristik Kemiskinan Anak di Daerah Perkotaan di Provinsi Bengkulu Tahun 2018

\begin{tabular}{llcc}
\hline \multirow{2}{*}{ Variabel } & \multicolumn{1}{c}{ Kategori } & \multicolumn{2}{c}{ Status Kemiskinan Anak (Persen) } \\
\cline { 2 - 4 } Tingkat Pendidikan KRT & CSMA & 23,96 & Tidak Miskin \\
\cline { 2 - 3 } Jenis Kelamin KRT & $\geq$ SMA & 8,12 & 76,04 \\
& Perempuan & 10,17 & 81,88 \\
Status Pekerjaan KRT & Laki-Laki & 7,24 & 92,83 \\
& Tidak Bekerja & 18,18 & 81,82 \\
& Informal & 15,04 & 84,96 \\
Ukuran Rumah Tangga & Formal & 13,42 & 86,58 \\
& $>4$ ART & 17,88 & 82,12 \\
Perilaku Menabung & $\leq 4$ ART & 10,01 & 89,99 \\
& Tidak Menabung & 21,43 & 78,57 \\
& Menabung & 8,92 & 91,08 \\
\hline
\end{tabular}

Sumber: PKL Mahasiswa Politeknik Statistika STIS TA 2017/2018 (diolah)

- Umur Kepala Rumah Tangga

Umur kepala rumah tangga yaitu umur dari seseorang yang bertanggung jawab untuk memenuhi kebutuhan sehari-hari rumah tangganya. Dalam penelitian ini, variabel umur kepala rumah tangga yang digunakan berupa data numerik. 


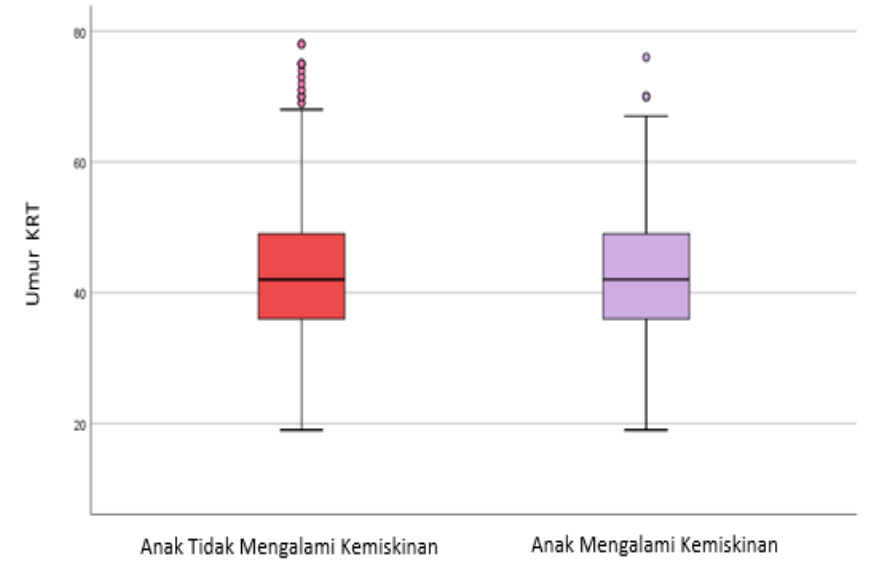

Sumber : PKL Mahasiswa Politeknik Statistika STIS TA 2017/2018 (diolah)

Gambar 3. Boxplot Sebaran Umur Kepala Rumah Tangga menurut Status Kemiskinan Anak di Daerah Perkotaan di Provinsi Bengkulu Tahun 2018.

Berdasarkan Gambar 3, boxplot pada kategori anak tidak mengalami kemiskinan menunjukkan bahwa umur minimum kepala rumah tangga adalah 19 tahun, sedangkan umur maksimum kepala rumah tangga adalah 78 tahun, dan median umur kepala rumah tangga adalah 42 tahun. Selanjutnya, boxplot pada kategori anak mengalami kemiskinan menunjukkan bahwa umur minimum kepala rumah tangga adalah 19 tahun, sedangkan umur maksimum kepala rumah tangga adalah 76 tahun, dan median umur kepala rumah tangga adalah 42 tahun. Kedua kategori memiliki median umur kepala rumah tangga yang sama.

- Tingkat Pendidikan Kepala Rumah Tangga

Berdasarkan Tabel 1, anak yang mengalami kemiskinan dan tinggal dengan kepala rumah tangga berpendidikan di bawah SMA memiliki persentase yang lebih tinggi daripada ketika tinggal dengan kepala rumah tangga berpendidikan SMA ke atas, dengan masing-masing persentase anak miskin sebesar 23,96 persen dan 8,12 persen. Hal ini mengindikasikan bahwa anak yang tinggal bersama kepala rumah tangga berpendidikan di bawah SMA memiliki risiko 2,96 kali lebih besar untuk mengalami kemiskinan dibandingkan tinggal bersama kepala rumah tangga yang berpendidikan SMA ke atas.

- Jenis Kelamin Kepala Rumah Tangga

Berdasarkan Tabel 1, persentase anak yang mengalami kemiskinan dan tinggal dengan kepala rumah tangga berjenis kelamin perempuan sebesar 10,17 persen dan lebih besar daripada ketika tinggal dengan kepala rumah tangga berjenis kelamin laki-laki dengan persentase anak yang mengalami kemiskinan sebesar 7,24 persen. Hal ini mengindikasikan bahwa anak yang tinggal bersama kepala rumah tangga berjenis kelamin perempuan memiliki risiko 1,41 kali lebih besar untuk mengalami kemiskinan dibandingkan tinggal bersama kepala rumah tangga berjenis kelamin laki-laki.

- Status Pekerjaan Kepala Rumah Tangga

Tabel 1 menunjukkan bahwa anak yang tinggal di daerah perkotaan dan tinggal dengan kepala rumah tangga yang tidak bekerja, 18,18 persennya merupakan anak yang mengalami kemiskinan. Persentase anak yang mengalami kemiskinan pada kategori kepala rumah tangga yang tidak bekerja lebih tinggi daripada dua kategori lainya, yaitu sebesar 15,04 persen anak yang mengalami kemiskinan ketika tinggal dengan kepala rumah tangga yang bekerja di sektor informal, sedangkan pada kategori kepala rumah tangga yang bekerja di sektor formal, sebesar 13,42 persen anak mengalami kemiskinan.

- Ukuran Rumah Tangga

Berdasarkan Tabel 1, dapat dilihat bahwa persentase anak yang mengalami kemiskinan tinggal di rumah tangga berukuran lebih dari empat orang sebesar 17,88 persen dan lebih tinggi daripada ketika tinggal di rumah tangga yang beranggotakan maksimum empat orang memiliki persentase sebesar 10,01 persen. Hal ini mengindikasikan bahwa anak yang tinggal dalam rumah tangga yang berukuran lebih dari empat orang memiliki risiko 1,79 kali lebih besar untuk mengalami kemiskinan dibandingkan tinggal dalam rumah tangga yang maksimum beranggotakan 
empat orang. Semakin besar ukuran rumah tangga akan menurunkan tingkat kesejahteraan akibat jumlah tanggungan yang semakin besar pula dalam rumah tangga tersebut sehingga berpeluang untuk mengalami kemiskinan Quartey (2006). Oleh karena itu, ukuran rumah tangga yang lebih besar maka semakin besar pula kemungkinan anak untuk mengalami kemiskinan.

- Perilaku Menabung

Tabel 1 juga menunjukkan persentase anak yang mengalami kemiskinan dan tinggal di rumah tangga yang tidak menabung sebesar 21,43 persen. Sedangkan anak yang mengalami kemiskinan dan tinggal di rumah tangga yang menabung memiliki persentase sebesar 8,92 persen. Hal ini mengindikasikan bahwa anak yang tinggal dalam rumah tangga yang tidak menerapkan budaya menabung memiliki risiko 2,40 kali lebih besar untuk mengalami kemiskinan daripada tinggal dalam rumah tangga yang menerapkan budaya menabung. Dampak kemiskinan yang dirasakan oleh anak bersifat kerusakan jangka panjang. Hak anak untuk menikmati pendidikan dan menjalani hidup yang layak dan berkualitas terampas karena ekonomi rumah tangga yang serba terbatas (Kumala et al., 2013). Menurut Pohan et al. (2014), menabung adalah sebuah keharusan. Terdapat dua peran penting tabungan dalam skala mikro atau rumah tangga, yaitu menjadi sarana pendanaan masa depan dan untuk mengatasi ketidakpastian pendapatan.

\section{Variabel-Variabel yang Memengaruhi Status Kemiskinan Anak yang Tinggal di Daerah Perkotaan di Provinsi Bengkulu Tahun 2018}

Pendugaan parameter model menggunakan metode backward elimination, dengan mereduksi satu-satu variabel yang tidak signifikan pada setiap tahapan. Variabel yang direduksi, yaitu jenis kelamin kepala rumah tangga $\left(D_{3}\right)$ dan status pekerjaan $\left(D_{41}\right.$ dan $\left.D_{42}\right)$. Hasil akhir metode backward elimination dapat dilihat pada tabel berikut.

Tabel 2. Hasil Regresi Complementary Log-Log.

\begin{tabular}{|c|c|c|c|c|c|c|}
\hline $\begin{array}{c}\text { Kode } \\
\text { Variabel }\end{array}$ & Variabel & $b$ & $S e(b)$ & Wald & $p$-value & $\operatorname{Exp}(b)$ \\
\hline & Konstanta & $-2,4047$ & 0,2963 & $-8,117$ & 0,000 & - \\
\hline $\mathrm{X} 1$ & Umur KRT & $-0,0199$ & 0,0065 & $-3,072$ & 0,002 & 0,9803 \\
\hline D2 & Tingkat Pendidikan KRT & 1,0797 & 0,1390 & 7,768 & 0,000 & 2,9437 \\
\hline D5 & Ukuran Rumah Tangga & 0,6712 & 0,1432 & 4,687 & 0,000 & 1,9565 \\
\hline D6 & Perilaku Menabung & 0,8082 & 0,1386 & 5,832 & 0,000 & 2,2438 \\
\hline
\end{tabular}

Berdasarkan Tabel 2, dapat dilihat bahwa tersisa empat variabel penjelas yang signifikan memengaruhi status kemiskinan anak yang tinggal di daerah perkotaan. Variabel-variabel penjelas yang dimaksud, yaitu umur kepala rumah tangga, tingkat pendidikan kepala rumah tangga, ukuran rumah tangga, dan perilaku menabung. Sehingga diperoleh persamaan regresi sebagai berikut:

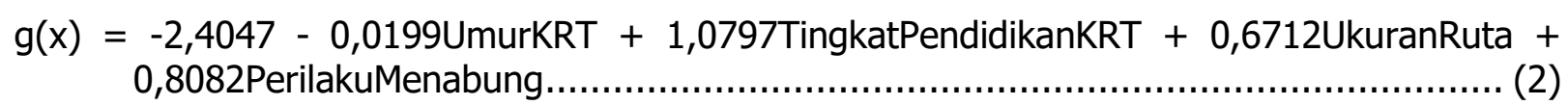

Hasil uji simultan dengan uji Likelihood Ratio (G) menunjukkan nilai G sebesar 140,3642. Karena nilai $G(140,3642)>X^{2}(0,05 ; 4)(9,4877)$, maka keputusan yang diambil tolak $\mathrm{H}_{0}$. Dapat disimpulkan bahwa dengan tingkat signifikansi lima persen, terdapat cukup bukti untuk menyatakan bahwa minimal terdapat satu variabel penjelas yang memengaruhi variabel status kemiskinan anak yang tinggal di perkotaan di Provinsi Bengkulu tahun 2018.

Hasil uji parsial dengan statistik uji Wald yang disajikan dalam Tabel 2 menunjukkan bahwa untuk setiap variabel penjelas memiliki $p$-value lebih kecil dari a yang sebesar 0,05 . Keputusan yang diambil adalah tolak $\mathrm{H}_{0}$. Maka dapat disimpulkan bahwa baik variabel umur kepala rumah tangga, tingkat pendidikan kepala rumah tangga, ukuran rumah tangga, dan perilaku menabung signifikan memengaruhi status kemiskinan anak yang tinggal di daerah perkotaan secara parsial.

Berdasarkan hasil pengujian kesesuaian model dengan Hosmer and Lemeshow Test, nilai $c$ yang diperoleh pada tahap terakhir sebesar 14,347 dan $p$-value sebesar 0,07315 . Karena $c$ 
$(14,347)<X^{2}(0,05 ; 8)(15,507)$ dan $p$-value $(0,07315)>$ a $(0,05)$, maka keputusan yang diambil adalah gagal tolak $\mathrm{H}_{0}$. Sehingga dapat disimpulkan bahwa model sesuai atau dengan kata lain tidak terdapat perbedaan yang signifikan antara hasil pengamatan dengan kemungkinan hasil prediksi model.

Penjelasan terkait nilai besaran risiko $[\operatorname{exp(b)]~untuk~masing-masing~variabel~penjelas~yang~}$ memengaruhi status kemiskinan anak yang tinggal di daerah perkotaan di Provinsi Bengkulu tahun 2018 berdasarkan Tabel 2 sebagai berikut.

- Umur Kepala Rumah Tangga

Berdasarkan Tabel 2, dapat dilihat bahwa nilai $\exp (\mathrm{b})$ untuk variabel umur kepala rumah tangga adalah sebesar 0,9803. Artinya, jika umur kepala rumah tangga bertambah satu tahun, maka seorang anak yang tinggal di perkotaan akan mengalami penurunan risiko untuk mengalami kemiskinan sebesar 1,020 kali, dengan asumsi tingkat pendidikan kepala rumah tangga, ukuran rumah tangga, dan perilaku menabung dianggap konstan. Apabila angka tersebut diinterpretasikan melalui median umur kepala rumah tangga, maka risiko seorang anak yang tinggal di perkotaan untuk mengalami kemiskinan anak ketika tinggal dengan kepala rumah tangga berusia 43 tahun akan lebih kecil dibandingkan ketika tinggal dengan kepala rumah tangga yang berusia 42 tahun. Hasil ini sejalan dengan penelitian oleh Ramadhani \& Munandar (2019) yang juga memperoleh hasil bahwa anak yang tinggal dengan kepala rumah tangga yang berusia tua kecenderungan untuk mengalami kemiskinan lebih kecil dibandingkan tinggal dengan kepala rumah tangga yang berusia lebih muda.

- Tingkat Pendidikan Kepala Rumah Tangga

Variabel tingkat pendidikan kepala rumah tangga memiliki nilai risiko sebesar 2,9437. Artinya, anak yang tinggal di daerah perkotaan dengan kepala rumah tangga berpendidikan di bawah SMA memiliki risiko untuk mengalami kemiskinan anak 2,9437 kali lebih besar dibandingkan anak dengan kepala rumah tangga berpendidikan SMA ke atas. Hasil ini sejalan dengan penelitian oleh Bachtiar et al. (2016)yang menyatakan semakin rendah tingkat pendidikan kepala rumah tangga, maka semakin tinggi peluang seorang anak untuk mengalami kemiskinan. Kemiskinan yang berlanjut antargenerasi diindikasikan karena tidak adanya kesempatan anak untuk bersekolah. Tingkat pendidikan akan sangat berguna saat anak tersebut menjadi dewasa, karena tingkat pendidikan menjadi salah satu faktor daya saing dalam pasar kerja.

- Ukuran Rumah Tangga

Nilai risiko untuk variabel ukuran rumah tangga adalah sebesar 1,9565. Artinya anak yang tinggal di daerah perkotaan dan tinggal pada rumah tangga yang beranggotakan lebih dari empat orang akan mengalami peningkatan risiko untuk mengalami kemiskinan sebesar 1,9565 kali lebih besar dibandingkan anak yang tinggal dalam rumah tangga yang maksimum anggota rumah tangga berjumlah empat orang. Hasil ini sejalan dengan penelitian Putnarubun (2018) yang menyatakan bahwa anak yang tinggal dalam rumah tangga dengan jumlah anggota rumah tangga lima orang atau lebih cenderung untuk mengalami kemiskinan anak daripada anak yang tinggal pada rumah tangga beranggotakan kurang dari lima orang.

- Perilaku Menabung

Variabel perilaku menabung memiliki nilai risiko sebesar 2,2438. Hal ini berarti, anak yang tinggal di daerah perkotaan dan tinggal di rumah tangga yang tidak menabung memiliki risiko untuk mengalami kemiskinan anak 2,2438 kali lebih besar daripada anak yang tinggal di rumah tangga yang menabung. Tabungan memegang peranan penting dalam modal di masa depan. Tabungan menjadi sarana pendanaan masa depan terutama membiayai pendidikan anak, pembiayaan kebutuhan akan kesehatan, dan untuk mengatasi ketidakpastian pendapatan dalam memenuhi kebutuhan ekonomi rumah tangga.

\section{KESIMPULAN}

Karakteristik anak yang mengalami kemiskinan yang tinggal di daerah perkotaan di Provinsi Bengkulu pada tahun 2018, yaitu anak yang tinggal dengan kepala rumah tangga berumur dewasa, anak dengan kepala rumah tangga berpendidikan di bawah SMA, anak dengan kepala rumah tangga berjenis kelamin perempuan, anak dengan kepala rumah tangga yang tidak bekerja, 
anak yang tinggal dalam rumah tangga dengan ukuran lebih dari empat anggota rumah tangga, dan anak yang tinggal dengan rumah tangga yang tidak memiliki perilaku menabung.

Hasil analisis dengan metode regresi complementary log-log menunjukkan bahwa terdapat empat dari enam variabel yang memengaruhi status kemiskinan anak di Provinsi Bengkulu pada tahun 2018. Variabel tersebut antara lain: umur kepala rumah tangga, tingkat pendidikan kepala rumah tangga, ukuran rumah tangga, dan perilaku menabung.

Risiko anak untuk mengalami kemiskinan lebih besar terjadi pada anak yang tinggal dengan kepala rumah tangga berusia lebih muda, anak dengan pendidikan kepala rumah tangga yang ditamatkan di bawah SMA, anak yang tinggal dalam rumah tangga yang berukuran lebih dari empat orang anggota rumah tangga, dan anak yang tinggal di rumah tangga yang tidak memiliki perilaku menabung.

\section{DAFTAR PUSTAKA}

Bachtiar, N., Rasbi, M. J., \& Fahmi, R. (2016). Analisis Kemiskinan Anak Balita pada Rumah Tangga di Provinsi Sumatera Barat. Jurnal Kependudukan Indonesia, 11(1), 29-38.

Badan Perencanaan Pembangunan Nasional, Badan Pusat Statistik, \& United Nations Population Fund. (2013). Proyeksi Penduduk Indonesia 2010-2035. Badan Pusat Statistik. https://doi.org/10.1007/BF00830441

Badan Pusat Statistik, \& UNICEF. (2017). Analisis Kemiskinan Anak dan Deprivasi Hak-Hak Dasar Anak di Indonesia. Badan Pusat Statistik.

Bartlett, S. (2012). Children in Urban Poverty: Can they get more than small change? United Nations Children's Fund (UNICEF), Division of Policy and Practice, October, 139-148. http://www.unicef.org/socialpolicy/index_62108.html

Bima, L., Nurbani, R., Diningrat, R., Marlina, C., Hermanus, E., \& Lubis, S. (2017). Urban Child Poverty and Disparity: The Unheard Voices of Children living in Poverty in Indonesia. SMERU Research Report Urban, 1-82. http://www.smeru.or.id/sites/default/files/publication/ucpd2017.pdf

Calabrese, R. (2014). Optimal cut-off for rare events and unbalanced misclassification costs. Journal of Applied Statistics, 41(8), 1678-1693. https://doi.org/10.1080/02664763.2014.888542

Heck, R. H. (2013). Multilevel Modeling of Categorical Outcomes Using IBM SPSS. In Multilevel Modeling of Categorical Outcomes Using IBM SPSS. https://doi.org/10.4324/9780203808986

Kumala, A. Z., Agustini, H. N., \& Rais. (2013). Dinamika Kemiskinan dan Pengukuran Kerentanan Kemiskinan dalam Upaya Melindungi Anak-anak dari Dampak Kemiskinan (Studi Kasus pada Rumah Tangga di Pulau Jawa Tahun 2008-2010). In Child Poverty and Social Protection Conference. SMERU Research Institute.

Pohan, L. H. M., Suroso, P. C., Pattiwael, J. F., \& Fordian, D. (2014). PERILAKU MENABUNG KELOMPOK MASYARAKAT BERPENGHASILAN RENDAH ( MBR ) DI PERKOTAAN DAN PERDESAAN: SEBUAH KAJIAN AWAL. Research Report - Humanities and Social Science, 2, 0-22.

Pusponegoro, N. H. (2013). Kemiskinan Anak Usia Kurang dari 5 Tahun pada Rumah Tangga dengan RataRata Pengeluaran yang Terletak pada Kuantil Pertama Tahun 2008-2010 di Indonesia. Child Poverty and Social Protection Conference.

Putnarubun, R. N. (2018). Analisis Status Kemiskinan Anak Balita pada Rumah Tangga di Provinsi Maluku Tahun 2016. Politeknik Statistika STIS.

Quartey, P. (2006). The Impact of Migrant Remmitances on Household Welfare in Ghana. In The African Economic Research Consurtium. AERC. https://opendocs.ids.ac.uk/opendocs/handle/20.500.12413/2669

Ramadhani, A. W., \& Munandar, A. I. (2019). DETERMINAN KEMISKINAN ANAK DI PROVINSI DKI JAKARTA: SUSENAS 2017. Jurnal Ekonomi Kuantitatif Terapan, 12(2), 111-123. https://doi.org/10.24843/jekt.2019.v12.i02.p01

United Nations. (2018). Convention on the Rights of the Child. https://www.unicef.org/indonesia/id/konvensi-hak-anak-versi-anak-anak

United Nations. (2019). Sustainable Development Goals Goal 1. https://sdgs.un.org/goals/goal1

World Bank. (2000). World Development Report 2000/2001: Attacking Poverty (Issue September). World Bank. 